MAJOR FIGURES IN SPANISH AND

\title{
LATIN AMERICAN LITERATURE
}

AND THE ARTS 


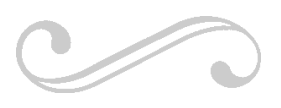

Major Figures in Spanish and Latin American Literature and the Arts will publish comprehensive books on canonical authors and artists from any period, adhering to a variety of approaches, but generally following the form of a literary biography. Grounded in thorough and original scholarship, and written in a jargon-free style, the books should be accessible to the educated nonspecialist. 


\title{
DELMIRA AGUSTINI, \\ SEXUAL SEDUCTION, AND \\ VAMPIRIC CONQUEST
}

\author{
Cathy L. Jrade
}

\author{
Yale \\ UNIVERSITY \\ PRESS
}

Nerw Haven and London 
Published with assistance from the Mary Cady Tew Memorial Fund.

Copyright (C) 2012 by Cathy L. Jrade. All rights reserved. This book may not be reproduced, in whole or in part, including illustrations, in any form (beyond that copying permitted by Sections 107 and 108 of the U.S. Copyright Law and except by reviewers for the public press), without written permission from the publishers.

Yale University Press books may be purchased in quantity for educational, business, or promotional use.

For information, please e-mail sales.press@yale.edu (U.S. office) or sales@yaleup.co.uk (U.K. office).

Set in Baskerville and Bulmer type by Tseng Information Systems, Inc.

Printed in the United States of America.

Library of Congress Cataloging-in-Publication Data Jrade, Cathy Login.

Delmira Agustini, sexual seduction, and vampiric conquest /

Cathy L. Jrade.

p. cm. - (Major figures in Spanish and Latin American literature and the arts)

Includes bibliographical references and index.

IS в 978-0-300-16774-o (cloth : alk. paper) 1. Agustini, Delmira, 1886-1914-Criticism and interpretation. I. Title. PQ8519.A5Z67 2012 $861^{\prime} .62-$ dc23 2011040636

A catalogue record for this book is available from the British Library.

This paper meets the requirements of ANSI/NISO Z39-48-1992 (Permanence of Paper).

10987654321 
For Ramón, Rachel, and Jonathann 
This page intentionally left blank 